Caryolopha sempervirens (L.) Fischer and Traut-

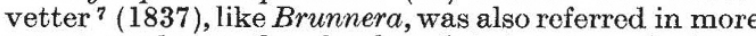
recent works to the closely related genus, Anchusa but on morphological grounds Johnston considered it also merited recognition as generically distinct from Anchusa.

A tabular comparison of Johnston's arrangement with that of Gürke, with a summary of my own cytological observations (Fig. 1), is given below.

\begin{tabular}{|c|c|c|c|c|c|c|}
\hline $\begin{array}{c}\text { Gürke's } \\
\text { Classification. }\end{array}$ & 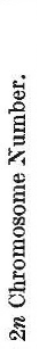 & \multicolumn{2}{|c|}{$\begin{array}{l}\text { Chromo- } \\
\text { some } \\
\text { Types } \\
\text { Classifled } \\
\text { according } \\
\text { to Position } \\
\text { of Point } \\
\text { of Attach- } \\
\text { ment. }\end{array}$} & $\begin{array}{l}\text { Chro } \\
\text { sol } \\
\text { Leng } \\
\text { Micr }\end{array}$ & $\begin{array}{l}\text { mo- } \\
\text { me } \\
\text { th in } \\
\text { ons. }\end{array}$ & $\begin{array}{l}\text { Johnston's } \\
\text { Classification. }\end{array}$ \\
\hline \multirow{5}{*}{$\begin{array}{c}\text { Anchusa Barrelieri } \\
\text { ochroleuca } \\
\text { seedling } \\
\text { italica var. } \\
\text { " ' Pride of } \\
\text { Dover, } \\
\text { offinalis }\end{array}$} & 16 & 24 & 10 & $4 \cdot 2$ & $6 \cdot 1$ & \multirow{7}{*}{ 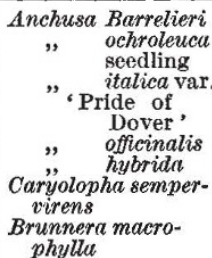 } \\
\hline & 24 & 3 & 15 & & 8.0 & \\
\hline & & & & & & \\
\hline & 32 & 46 & 22 & $4 \cdot 7$ & $8 \cdot 5$ & \\
\hline & 16 & 2 & 8 & $5 \cdot 9$ & $\begin{array}{l}8 \cdot 5 \\
7.8\end{array}$ & \\
\hline $\begin{array}{ll}\text { " } & \text { hybrida } \\
\text { semper- }\end{array}$ & $\begin{array}{l}16 \\
22\end{array}$ & $\begin{array}{ll}2 & 6 \\
4 & 6\end{array}$ & $\begin{array}{r}8 \\
12\end{array}$ & $\begin{array}{l}5 \cdot 2 \\
1.8\end{array}$ & $\begin{array}{l}7 \cdot 8 \\
3 \cdot 8\end{array}$ & \\
\hline $\begin{array}{c}\text { virens } \\
\text { myosotidi }- \\
\text { flora }\end{array}$ & 12 & $\begin{array}{ll}4 & 2\end{array}$ & 6 & $1 \cdot 4$ & $3 \cdot 0$ & \\
\hline
\end{tabular}

It is apparent that Johnston's changes in classification are fully substantiated by the microscopical observations, for both Brunnera and Caryolopha differ markedly from each other and from Anchusa in size, type and number of chromosomes. Nevertheless,
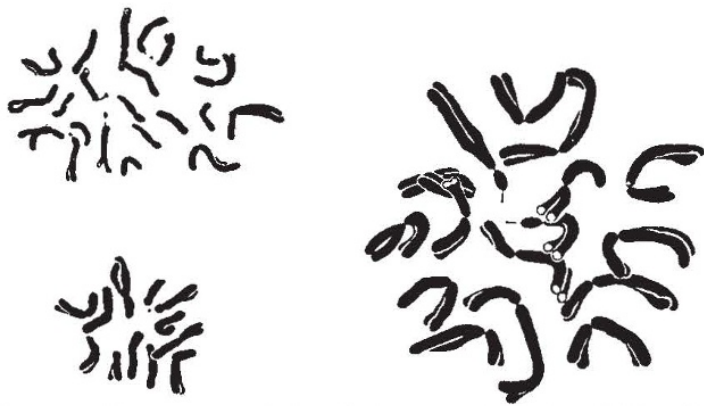

FIG. 1.-Chromosomes of Caryolopha sempervirens (top left hand); Brunnera macrophylla (bottom left hand); Anchusa officinalis (right).

while recognising that collectively these differences justify the generic changes, there is to be seen a definite similarity between certain chromosomes of all three genera which may possibly indicate the moderately close relationship which Johnston assumes exists between them.

In a less abbreviated account to be published shortly, it is hoped to indicate more fully the value of cytology as a corroborant of herbarium methods in the classification of plants.

Department of Botany,

S. G. Sмiтh.

McGill University, Montreal.

1 "Plantæ et Familia Asperif. nuciferæ descripsit." Berlin ; 1818.

2 “ Fl. Taur.-Cauc.", 1, Leipzig; 1808 .

3 Bull. Soc. Nat. Moscov., 24, 1 ; 1851.

- Contrib. Gray Ierb. of Harvard Univ., 73; 1924.

- Curtis's Bot. Mag., 151, Tab. 9110 ; 1925.

- In Engler and Pranti, “Die naturliche Pflanzenfamilien", 4, Abt. 3a: 71-131. Leipzig, 1893.

Ind. Sem. Hort. Petrop., 3; 1837.

No. 3229, VoL. 128]

\section{Thrips tabaci as a Vector of Plant Virus Disease.}

IN NATLRE of June 6, Dr. Kenneth Smith reports finding Thrips tabaci Lind. to be a vector of tomato spotted wilt in Fngland. Since recent Australian work on the transmission of this disease has not yet been published, the following particulars may also be of intorest :

The first record of successful insect transmission of tomato spotted wilt was made by Pittman, ${ }^{1}$ who described three experiments with thrips; the insects used in the last of these experiments were identified by an entomologist as Thrips tabaci. Later, Samuel, Bald, and Pittman published a bulletin, ${ }^{2}$ in which the main vector of the disease in South Australia was claimed to be the thrips Frankliniella insularis Franklin. In this bulletin a number of experiments with Thrips tabaci were recorded which proved negative, but the possibility that 'Thrips tabaci might act as a vector was not yet excluded. This was because transmission, even with Frankliniella insularis, was often so irregular that it was felt that some unknown factor influencing transmission had not been discovered. Another fact which indicated that Frankliniella insularis was not the only vector was that spotted wilt was a serious disease in Victoria, although Frankliniella insularis was extremely rare in Victoria.

In a bulletin now in the press, further work on transmission with Frankliniella insularis is described, in which it was found that when adult thrips were fed on a diseased plant and then transferred to healthy plants the disease was never transmitted. For successful transmission to occur, it proved to be essential that the thrips should have fed on the diseased plant in the larval stage. No analogous case with other insect vectors of virus diseases appears to have been described yet. (One of the writers, G. S., however, was much interested to find, on passing through Honolulu recently, that Dr. M. B. Linford, of the Hawaiian Pineapple Growers' Experiment Station, had discovered that Thrips tabaci, the insect vector of the yellow-spot disease of pineapple, was also unable to transmit the disease unless it had fed on a diseased plant during its larval stage.)

With this additional information of transmission, and also the fact that the incubation period of the virus in the thrips (Frankliniella) was found to be between five and seven days, the experiments with Thrips tabaci are being repeatod. Already this species has been found to act as a vector of spotted wilt, as originally claimed by Pittman, and as now verified independently from England by Dr. Kenneth Smith. It is not yet known whether this, or possibly still another species of thrips, is the vector of the disease in Victoria. Several facts, however, suggest that in South Australia Frankliniella insularis is a more 'efficient' vector of the disease than Thrips tabaci.

Dr. Smith's observations on dahlia plants infected with spotted wilt are also interesting. In our forthcoming bulletin, besides thirty species of Solanacea, three species in the Compositce and one each in the Papaveraceoe and Tropceolacece are proved to be hosts for the spotted wilt virus.

Waite Agricultural Research Institute, University of Adelaide. J. G. BALD.

Council for Scientific and Industrial Research of Australia, July 24.

1 Jour. Counc. Sei. and Ind. Res. Aust., 1, 74; 1927. 